\title{
Bezpieczne i higieniczne warunki pracy w zatrudnieniu cywilnoprawnym
}

\section{Safe and healthy working conditions in civil law employment}

\author{
dr Michat Raczkowski
}

Uniwersytet Warszawski, Wydział Prawa i Administracji,

Katedra Prawa Pracy i Polityki Społecznej m.raczkowski@wpia.uw.edu.pl

ORCID: 0000-0001-5585-9101

\begin{abstract}
Streszczenie Konstytucja Rzeczypospolitej Polskiej zapewnia każdemu bezpieczne i higieniczne warunki pracy (art. 66 ust. 1). W tak stanowczym brzmieniu obejmuje więc ona nie tylko stosunki pracy, ale także stosunki prawne zatrudnienia cywilnoprawnego. Zastosowana metoda regulacji polegająca na powieleniu zasad ochrony przewidzianych dla pracowników budzi jednak szereg zaprezentowanych w artykule wątpliwości teoretycznych i praktycznych.
\end{abstract}

Słowa kluczowe: zatrudnienie niepracownicze, bezpieczeństwo i higiena pracy.

Summary Constitution of the Republic of Poland (art. $66 \mathrm{sec} .1$ ) guarantees everyone a right to safe and healthy working conditions. This covers both labour law employment relationships as civil law employment ones. However a method of regulation - simple widening of rules applicable to labour employment — constitutes several theoretical and practical doubts hereby presented.

Keywords: civil law employment, safe and healthy working conditions.

JEL: K31

Str. 66-70

\section{Bibliografia}

Jończyk, J. (1995). Prawo pracy. Warszawa.

Lewandowicz-Machnikowska, M. (2018). Osoba fizyczna jako pracodawca. Przeglad Prawa i Administracji, CXII. Wrocław.

Liszcz, T. (2013). Konstytucyjna zasada ochrony pracy. W: G. Uścińska (red.), Prawo pracy. Refleksje i poszukiwania. Księga jubileuszowa prof. Jerzego Wratnego. Warszawa.

Nowacki, J. (1964). Odpowiednie stosowanie przepisów prawa. Państwo i Prawo, (3).

Nycz, T. (2008). W: B. Wagner (red.), Kodeks pracy. Komentarz. Gdańsk.

Prusinowski, P. (2018). Uwagi do art. 304. W: K. W. Baran (red.), Kodeks pracy. Komentarz. Warszawa.

Szubert, W. (1966). Ochrona pracy. Studium społeczno-prawne. Warszawa.

Szubert, W. (1976). Zarys prawa pracy. Warszawa.

Wyka, T. (2000). Bezpieczeństwo i ochrona zdrowia w zatrudnieniu niepracowniczym typu cywilnoprawnego. W: Z Ku- bot (red.), Szczególne formy zatrudnienia. Wrocław.

Wyka, T. (2003). Ochrona zdrowia i życia pracownika jako element treści stosunku pracy. Warszawa.

Wyka, T. (2007). Konstytucyjne prawo każdego do bezpiecznych i higienicznych warunków pracy a zatrudnienie na innej podstawie niż stosunek pracy oraz praca na własny rachunek - uwagi de lege ferenda. W: Człowiek, uczony, obywatel. Księga jubileuszowa prof. Urszuli Jackowiak. Gdańsk. 